\title{
GIL, José. Cansaço, tédio e desassossego. Lisboa: Relógio d’Água, 2013. 128 p.
}

O livro de José Gil Cansaço, tédio e desassossego é composto por quatro ensaios: "O corpo de Caeiro", "A morte de Caeiro": uma ou várias estéticas pessoanas?, "A heteronímia revisitada", "Cansaço, tédio, desassossego".

Trata-se de um macrotexto que ultrapassa a mera noção de quatro ensaios seriados, já que do conjunto ressalta uma unidade, uma arte de pensar Pessoa, com lucidez interpretativa inovadora, no que diz respeito aos mecanismos de construção da subjectividade heteronímica, com particular relevo para Alberto Caeiro e para o semi-heterónimo Bernardo Soares.

José Gil parte da mestria de Alberto Caeiro como ciência e prática do ver e do sentir. Como "entrada na imanência" ou "construção do plano da imanência da Natureza" - "saber sentir ou ver é ver ou sentir sem metafísica", - num processo de desaprendizagem para chegar ao despojamento que permita a verdadeira percepção das coisas "ver uma coisa tal qual ela é", ou ainda - "Bendito seja eu por tudo o que não sei".

É preciso "esquecer" o que se aprendeu, "arrancar a ideia associada à percepção", procedendo a "uma verdadeira extracção dos conteúdos aprendidos e sedimentados, fazer uma "desincorporação" ou "desinteriorização" dos estratos integrados, "raspar a tinta" com que pintaram os sentidos, realizando, por esta forma, "uma espécie de intuição intelectual dos sentidos".

José Gil dilucida a noção de "hemorragia do sentido", os significados reenviando para outros significados, até ao infinito. E todavia, as coisas "não têm significado, têm apenas existência". Esta a doença metafísica: a busca do sentido último do mistério - "Perseguimos cada significado até ao infinito, corremos de um para outro, na ânsia de formar totalidades de sentido que unifiquem o Universo."

José Gil monstra que Caeiro surge como resposta viva a todos os problemas que obcecam Reis, Campos, Soares, Pessoa ortónimo. "Para ele não há cisão interior, distância que vai de nós a nós mesmos, ou de nós a outrem, a morte não é uma catástrofe, o tempo não existe, não existe infinito". Todavia, em Caeiro, "a ausência de cisão não pressupõe uma unidade fundamental primitiva, uma coincidência original de nós connosco mesmos e com o cosmos", mas antes "uma coexistência harmoniosa com a multiplicidade diferencial do mundo".
Caeiro é o sujeito de toda a heteronímia, é a própria heteronímia realizada, já que é o que "permanece quando o sujeito da escrita atravessa todos os devir-outros heteronímicos e desaparece enquanto "eu". Ao contrário da hiperconsciência de Campos, Caeiro "dispersa" e reabsorve a sua consciência de si na multiplicidade das sensações singulares, integrando o pensamento na sensação. Daí a ausência de subjectividade no "Argonauta das sensações verdadeiras", viajante da multiplicidade das sensações. José Gil complexifica, e simultaneamente ilumina a co-existência de dois Caeiros no poeta pagão - "um visível na escrita e outro invisível, para o qual o enunciado incessantemente nos remete - um Caeiroreal-ao-sol, em harmonia com a Natureza, na origem da enunciação."

Fernando Pessoa apresenta Caeiro como fruto de toda uma elaboração da História: o mestre "sensacionista", "neopagão" que traz um olhar novo sobre a Natureza, "após vinte séculos" de religiões, de filosofias, de correntes literárias. José Gil mostra que Caeiro não resolve as aporias da consciência e da inconsciência, do natural e do artificial, do primitivo e do civilizado: dissolve-as, passa ao lado das contradições.

"Procuro dizer o que sinto/Sem pensar que o sinto./ Procuro encostar as palavras á idéa/E não precisar dum corredor/Do pensamento para as palavras."

Conclui-se, por esta forma, que o corpo de Caeiro realiza o plano da imanência, caracterizando-o como um corpo em que os sentidos se concentram ou se condensam num só - a visão, que contrai em si o olfacto, o tacto, o gosto, a audição e todas as funções corporais de relação com o mundo. O corpo de Caeiro caracteriza-se ainda como "exterioridade" absoluta, um corpo idêntico ao dos deuses - "A alma é-lhes corpo". Por último, e paradoxalmente, - um corpo singular, individual, se bem que impessoal, que se confunde com o Universo: "Trago ao Universo um Novo Universo/Porque trago ao Universo ele-próprio."

José Gil não enjeita a função modelar de professor que é, clarificando as noções de "estética" como "estudo da organização das sensações com o fim de produzir um objecto artístico " e de "poética" como lógica da organização da linguagem com vista a produzir textos com determinadas características literárias". Assim, 
conclui que enquanto os heterónimos supõem poéticas diferentes - como o testemunha a Conversa em família -, não é evidente que cada um implique uma estética própria. $\mathrm{O}$ ensaísta mostra que existe uma única estética pessoana, "a estética do sensacionismo, a estética das multiplicidades, a estética da diferença e "o poder da lógica desta estética vai ao ponto de construir uma constelação de autores fictícios distintos, mas que têm entre eles relações de parentesco, subordinadas a uma relação dominante que condiciona toda a dinâmica do conjunto" - relação de fascínio pela figura do argonauta das "sensações verdadeiras" - Alberto Caeiro.

Até mesmo na paróquia heterónima é preciso "matar o Pai". José Gil mostra-nos, com argúcia, a "necessidade" da morte de Caeiro para permitir a sobrevivência da família heteronímica, já que desaparecendo o mestre para sempre, funda ontológicamente as diferenças (modais) entre os heterónimos, seus discípulos. Como no verso de Cesário, se Caeiro não morresse nunca, os outros heterónimos não seriam necessários, pois "dele emanariam as sensações infinitas e infinitamente diversas que permitiriam "sentir tudo de todas as maneiras", sem ter de recorrer a Álvaro de Campos ou Bernardo Soares." Só a morte de Caeiro "produz essa transformação, essa mitificação do real de um ideal inacessível, assegurando ao mesmo tempo a realidade poética, actual, dos que procuram aceder a ele."

No ensaio epónimo, revelam-se muito subtis as distinções entre tédio, cansaço, desassossego, mas também inquietude e angústia n' O livro do desassossego, que Jorge de Sena considerou (e José Gil subscreve) como "imenso terreno onde fervilham embriões de escrita de outros heterónimos". Forçoso é destacar a finíssima análise do tédio como clausura da cela infinita. Como aborrecimento do mundo, mal-estar de estar vivendo, cansaço de ter vivido. Antecipação de tédio em emaranhamento - "a pena, já, de amanhã ter pena de ter tido pena hoje".

O cansaço como "um peso da consciência do mundo", que "implicará a paragem do desassossego, o cansaço intenso e o aborrecimento de tudo", para terminar na belíssima síntese da fuga impossível: "Mas o que tem tédio sente-se preso em liberdade fruste numa cella infinita".

José Gil, por vários caminhos e por múltiplas formas, mostra que não existe "eu", que todo o "eu", na heteronímia de Pessoa, é uma construção fictícia. É justamente para tornar esta ideia mais evidente que os heterónimos têm nomes, traços físicos, biografias. Convém lembrar a carta de 13 de Janeiro de 1935 a Casais Monteiro:

Fixei aquilo tudo em moldes de realidade. Graduei as influências, conheci as amizades, ouvi dentro de mim, as discussões e divergências de critérios, e em tudo isto me parece que fui eu, criador de tudo, o menos que ali houve. Parece que tudo se passou independentemente de mim. E parece que assim se passou.

Há uma pergunta, que faço a mim mesma, que me surgiu durante a leitura deste livro de José Gil: o "papel de cópia", que Fernando Pessoa usou para escrever a célebre carta a Casais Monteiro, além ter a função de suporte físico da escrita não será ele mesmo metonímia do conteúdo da carta?

TERESA MARTINS MARQUES CLEPUL

Recebido: 08 de dezembro de 2014 Aprovado: 14 de janeiro de 2015 Contato: tmartinsmarques@gmail.com 